\title{
Parenting style and empathy in children: The mediating role of family communication patterns
}

\author{
Sarrah Hasyim Abdullah ${ }^{1}$, Rose Mini Agoes Salim² \\ ${ }^{1,2}$ Faculty of Psychology, Universitas Indonesia, Indonesia \\ 1 sarrah.hasyim@gmail.com, ${ }^{2}$ romy.prianto@gmail.com
}

\section{ARTICLE INFO}

Article history

Received 15 May 2019

Revised 6 January 2020

Accepted 6 January 2020

Keywords

children

empathy

family communication patterns

parenting style

\begin{abstract}
Behavior problems among children in Indonesia are still high. The number of children involved in legal problems shows that there are existing moral problems. A crucial component in morals is empathy. Family, as the primary system in a child's life, has a significant influence on the development of empathy in children. This research was conducted to analyze the effect of parenting style on empathy in children through family communication patterns in early childhood in Indonesia. As many as 233 parents of 6 - 8-year-old children participated in this study. The Parental Authority QuestionnaireRevised, Basic Empathy Scale - Parent Report (BES-PR) and Family Communication Patterns-Revised (FCP-R) were used to collect the data. The results of this study indicate that family communication patterns mediate the relationship between parenting style and empathy in children. Conversational communication pattern mediate the effect of both authoritative parenting and permissive parenting on child's empathy independently. Conformity communication pattern only mediate the influence of authoritarian parenting on empathy in children. The current findings add information about the understanding about parenting strategies and interactions as well as the role of the family in the development of empathy in children.
\end{abstract}

\section{Introduction}

Moral intelligence is important and must be developed optimally starting from early childhood. Morality help children to distinguish between right and wrong, accept rules, and regulate their behavior towards other individuals (Berns, 2013). Therefore, moral intelligence in children could support children's life success at home, school, as well as the wider social environment.

Low moral values among children could cause various behavioral problems, wherein in Indonesia, the number of crimes committed by children is relatively high. Komisi Perlindungan Anak Indonesia (KPAI) stated that the level of complaints related to cases of Children Against the Law [Anak Berhadapan dengan Hukum - ABH] always ranks highest since 2011 - 2017 compared to 1,885 other cases involving children (Primastika, 2018). In 2018 , KPAI received 1,434 ABH; an increased from the previous year's number of cases $(\mathrm{N}=$ 1,403) (Halim, 2019). In the case of $\mathrm{ABH}$, the most frequent identified cases were children as perpetrators of sexual violence, followed by children as perpetrators of physical violence, and lastly, as perpetrators of murders.

The Bulungan Criminal Investigation Unit (Satreskrim) highlighted that the cases of children who deal with the law for committing crimes increased by $43 \%$ in 2017 , reaching 25 cases including theft, immorality, and human trafficking ("Children as Criminals Increase," n.d.). This data depicts the high level of violence committed by children in Indonesia, 
reflecting their state of empathy. Behavioral problems among children such as violence, aggression, and crime are indication of the lack of empathy in children (Borba, 2001).

Empathy is one of the main components in morality. Empathy is the ability to feel and imagine the emotional experiences of others (McDonald \& Messinger, 2011). Baron-Cohen and Wheelwright (2004) described empathy as the ability to change one's perspective, understand the feelings of others, and show appropriate emotional responses to the emotional state of others spontaneously.

Recent studies show that positive empathy lead to the emergence of prosocial behavior (Morelli, Lieberman, \& Zaki, 2015; Telle \& Pfister, 2015), feeling of social connection, and subjective well-being (Morelli et al., 2015). Additionally, a research conducted by Gantiva and Cendales (2018) showed that aggressiveness is negatively associated with cognitive empathy, but not with affective empathy. The results of these studies show the importance of empathy in a child's life. Children learn empathy from their surroundings, one of which is through the imparting of values given by parents to children.

Parents are the central and closest figure in a child's life. The ecological theory proposed by Bronfenbrenner (Santrock, 2011) explained that parents are included in children's microsystem, where their interactions could have a direct influence on children. Kong et al., (2018) stated that parents contribute to the genetic variation as well as the environmental condition that could impact their children's development. In line with this statement, Kiare (2015) discovered that parents carry characteristics that affect children's moral development, such as age, socioeconomic status, parental education, family structure, and values.

Child development is influenced by parenting strategies (Sangawi, Adams, \& Reissland, 2015). Akhtar (2012) stated that parenting style is a broad pattern regarding childcare practices, values, and behavior, in which the way parents care for children will have an impact on children's personality and social development. Parenting is quite complicated because it involves a variety of specific traits and behaviors that work separately and collectively. Later, this could significantly impact the child, particularly in terms of the parent-child emotional attachment (Darling \& Steinberg, 1993).

Hoffman (2000) stated that parenting style is one of the factors that influence the development of empathy in children. Empathic parents could contribute to developing empathy in children. This statement is supported by research conducted by Solfema (2013), which found that parenting style has a significant relationship with child empathy through socialization and caring behavior. Parenting style relates to children's emotion regulation, later producing empathy within themselves. Although studies have found a relationship between parenting style and child empathy, researchers have recently begun to realize the importance of investigating interactions between various variables to analyze empathy appropriately (Gilli, 2016). Cornell \& Frick (2007) discovered that, despite the negative relationship between authoritarian parenting style with empathy development, the earlier parenting style remains to be most beneficial for children with behavioral inhibition. This shows that the development of empathy is caused by the interaction of more than one variable. In the case from Cornell \& Frick (2007), the additional variables were temperament and parenting style. Hence, involving other variables is a necessary step when exploring the causal factors in empathy development.

The developmental perspective view the family as an essential agent in socializing values, beliefs, and behaviors that are considered appropriate and vital by the family members and community of the children (Shaffer \& Kipp, 2014). Koerner \& Fitzpatrick (2002) developed the concept of family communication patterns, used to gain understanding about family discourse and the mechanisms that occur within families in fostering teaching and learning related to values, beliefs, and attitudes. Regarding children's empathy, Vieira (2015) suggested that family communication patterns have a relationship with young girls' ability to empathize. This research shows the contribution of family communication patterns to the development of empathy in children. 
Communication that occurs in a family will form a pattern that is different from other families. Koerner \& Fitzpatrick (2002) identified two dimensions in the family communication pattern concept, namely, conversation and conformity orientation. Conversation orientation is the extent to which families support their family members to act freely and comfortably in interactions, discussions, and communication related to specific issues. On the other hand, conformity orientation is explained as to how far the family emphasizes the same attitudes, values, and beliefs among family members (Koerner \& Fitzpatrick, 2002). Farokhzad (2015) stated that communication in the family system is related to parenting styles and could influence children. Through his research, Farokhzad (2015) proved that the three dimensions of parenting style, namely authoritative, authoritarian, and permissive, have a significant relationship with the dimensions of family communication patterns, namely conversation and conformity orientation.

Family, as the primary system in a child's life, has a considerable influence on the development of child empathy. Some of their influences are through parenting style and family communication patterns. Therefore, parents' influence, depending on the child's age and stage of development, will occur throughout the life of the child. The Life-Span Perspective mentioned that multidimensional is one of the characteristics of development. This indicates that age, body, mind, emotions, and individual relationships change and influence each other (Santrock, 2011). It shows that age differences may influence and change the relationships that exist between individuals.

Research conducted by Farokhzad (2015) showed that there is a relationship between parenting style and family communication patterns in young adults. However, there is still limited information about the relationship between parenting style and family communication in early childhood. Besides the age difference, the current research was also conducted in Indonesia, highlighting a different cultural context from previous research. Belsky (2005) stated that some findings indicate that family race-ethnicity, children's emotions, and genetic characteristics influence the effects of parenting on children. Therefore, this study was conducted to discover the effect of parenting style on children's empathy through family communication patterns in early childhood participants.

\section{Method}

\section{Participants and Procedures}

The data was obtained from a sample of parents of first and $2^{\text {nd }}$-grade students at six elementary schools in Jakarta. This is a cross-sectional study, using convenience sampling to collect data from parents who were available to volunteer as participants. The participants consisted of 233 parents, with characteristics of having children with ages ranging from 6-8 years. Participants filled out the questionnaire using a printed booklet in Bahasa Indonesia. The research procedure was carried out by collaborating with the school to ask permission and distribute questionnaires to parents of students from the first and $2^{\text {nd }}$ grade. Parents are allowed to fill-out the questionnaire at home and return it to school the next day.

\section{Measurements}

The Parental Authority Questionnaire-Revised (Reitman, Rhode, Hupp, \& Altobello, 2002) was used to measure participants' parenting style. The PAQ-R consists of three dimensions: 1) Authoritarian, with the item example of "It is for my children's own good to insist that they do what I think is right, even if they don't agree"; 2) Authoritative, with the item example of "I always encourage discussion when my children feel family rules and restrictions are unfair"; and 3) Permissive, with an item example of "I usually don't set firm guidelines for my children's behavior". Adaptation to the PAQ-R was made by translating it into Bahasa Indonesia and reducing the number of items from 30 to 21 items. The item reductions were 
based on the cultural context in Indonesia. Each dimension consists of seven items measured using the six-point Likert scales from "strongly disagree" to "strongly agree". Items about the authoritarian sub-scale have a discrimination index between .40 to .53, and a Cronbach Alpha value of .73. Authoritative sub-scale items have a discrimination index between .26 to .44 and a Cronbach Alpha value of .65. On the permissive sub-scale, items have a discrimination index between .25 to .37 and a Cronbach Alpha value of .57 .

Child's Empathy was measured using the Basic Empathy Scale - Parent Report (Sánchez-Pérez, Fuentes, Jolliffe, \& González-Salinas, 2014). The current researchers translated the scale into Bahasa Indonesia through a back-translation process, expert judgment for validation, and pilot trial. We also made it into a short form consisting of seven items, removing the item with the lowest score based on item analysis. The dimensions of the BES-PR scale consists of two dimensions, namely affective empathy (i.e., S/he does not see other people crying) and cognitive empathy (i.e., S/he can often understand how people feel even before they tell her/him). BES-PR uses a 6-point Likert scale ranging from "strongly disagree" to "strongly agree", with higher scores indicating higher empathy. The items have a discrimination index between .20 to .45 and a Cronbach Alpha value of .57.

Family Communication Patterns was measured using the Family Communication Patterns-Revised (FCP-R) (Koerner \& Fitzpatrick, 2002). The adapted measuring instrument consists of nine items with two subscales: conformity orientation (i.e., I often say things like, 'You should give in on arguments rather than risk making people mad) and conversation orientation (i.e., My child can tell me almost anything). Measurements were made using a 6Likert scale ranging from one (strongly disagree) to six (strongly agree). Five items on the conformity orientation sub-scale have a discrimination index between .37 to .51 , and a Cronbach Alpha of .68; and four items on the conversation orientation sub-scale have a discrimination index between .34 to .43 and a Cronbach Alpha value of .59.

The Cronbach Alpha results obtained on the three instruments used in this study are in the range of .50 to .70. According to Hinton, Brownlow, McMurray, and Cozens (2004), Cronbach Alpha value in the range of .50 to .70 is included in the classification of moderate reliability.

\section{Data Analysis}

Pearson correlation and multiple regression were used to analyze the data. Pearson Correlation was used to examine the relationship between Parenting Style and Child's Empathy. Additionally, Multiple Regression using Hayes' PROCESS was used to examine the role of Family Communication Patterns as a mediator between Parenting Style and Child Empathy.

\section{Results}

Table 1 presents the mean value, standard deviation (SD), and the correlation between variables. Table 1 depicts that parenting style, particularly authoritative parenting and permissive parenting, significantly correlates with child empathy. The correlation of authoritative parenting with child's empathy is positive $(r=.26, p=.00)$, while permissive parenting correlate negatively with child empathy $(\mathrm{r}=-.24, \mathrm{p}=.00)$. These results indicate that the more authoritative parenting style is applied, the higher the child's empathy. Meanwhile, the more permissive parents are, the lower the empathy that the child develops.

Table 1 also indicates that parenting style has a correlation with family communication patterns. Authoritarian parenting has a positive correlation with both conformity family orientation $(\mathrm{r}=.54, \mathrm{p}=.00)$ and conversation family orientation $(\mathrm{r}=.23, \mathrm{p}=.00)$. Additionally, permissive parenting also has a positive correlation with both family communication patterns, with the strength of the conformity orientation correlation $(r=.15$, 
$\mathrm{p}=.01)$ and conversation orientation $(\mathrm{r}=.17, \mathrm{p}=.00)$. These findings show that, when parents apply authoritarian and permissive parenting, families tend to use both communication patterns, namely by showing mutual support to interact, discuss, and communicate freely and comfortably (conversation orientation), as well as uniformity regarding attitudes, values, and beliefs between family members (conformity orientation). In contrary, authoritative parenting only correlates with conversation orientation $(\mathrm{r}=.46, \mathrm{p}=.00)$. The more dominant authoritative parenting style is applied, the more family members tend to support each other to interact, discuss, and communicate freely and comfortably (conversation orientation).

Table 1 also shows that child empathy has a positive correlation with both family communication patterns: conformity orientation $(\mathrm{r}=.26, \mathrm{p}=00)$ and conversation orientation $(\mathrm{r}=.27, \mathrm{p}=.00)$. The correlation shows that, when family support each other to interact, discuss, and communicate freely and comfortably (conversation orientation) nor emphasize on uniformity regarding attitudes, values, and beliefs among family members (conformity orientation), children could increase their empathy.

Table 1

Means, Standard Deviations, and Correlations between Each Pair Variables

\begin{tabular}{|c|c|c|c|c|c|c|c|c|}
\hline Variables & Mean & SD & 1 & 2 & 3 & 4 & 5 & 6 \\
\hline 1.Child Emp. & 31.40 & 4.18 & - & & & & & \\
\hline 2.Authoritarian & 29.66 & 5.12 & -.11 & - & & & & \\
\hline 3.Authoritative & 36.16 & 3.10 & $.26 * *$ & & - & & & \\
\hline & & & & $.31 * *$ & & & & \\
\hline 4.Permissive & 19.44 & 4.55 & $-.24 * *$ & .12 & .02 & - & & \\
\hline 5.Conformity Orientation & 18.87 & 4.32 & $.26 * *$ & $.54 * *$ & .11 & $.15^{*}$ & - & \\
\hline 6.Conversation Orientation & 19.03 & 2.82 & $.27 * *$ & $.23 * *$ & $.46 * *$ & $.17 *$ & .08 & - \\
\hline
\end{tabular}

Note: $* * p<.01, * p<.05$.

Table 2 shows that: 1) Authoritarian parenting has a significant effect on child empathy $(\beta=-.15, p=.00) ; 2)$ Authoritative parenting has a significant effect on child empathy $(\beta=.42, p=.00)$; and 3$)$ Permissive parenting has a significant effect on child empathy $(\beta=-.20, p=.00)$.

Table 2

\section{Regression Test between Parenting Style and Child's Empathy}

\begin{tabular}{|c|c|c|c|}
\hline \multirow{2}{*}{ Antecedent } & \multicolumn{3}{|c|}{ Total Effect } \\
\hline & Coeff. & SE. & $P$ \\
\hline $\mathrm{X}_{1}$ (Authoritarian) & -.15 & .05 & $.00 *$ \\
\hline $\mathrm{X}_{2}$ (Authoritative) & .42 & .09 & $.00 *$ \\
\hline $\mathrm{X}_{3}$ (Permissive) & -.20 & .06 & $.00 *$ \\
\hline Constant & 24.53 & 3.33 & $.00 *$ \\
\hline $\mathrm{F}$ & \multirow{2}{*}{\multicolumn{3}{|c|}{12.70}} \\
\hline $\mathrm{R}^{2}$ & & & \\
\hline
\end{tabular}

Table 3 shows that parenting style affects empathy in children through family communication patterns. In more detail, the findings show that: 1) Conversational communication pattern mediates the effect of authoritative parenting on empathy in children $(\beta=.40 ; p=.00)$ as well as permissive parenting to empathy in children $(\beta=.01 ; p=.01)$; and 2) Conformity communication pattern only mediate the influence of authoritarian parenting on empathy in children $(\beta=.46 ; \mathrm{p}=.00)$. 
Table 3

Multiple Regression

\begin{tabular}{|c|c|c|c|c|c|c|c|c|c|}
\hline \multirow{2}{*}{ Antecedent } & \multicolumn{3}{|c|}{$\mathrm{M}_{1}$} & \multicolumn{3}{|c|}{$\mathrm{M}_{2}$} & \multicolumn{3}{|c|}{$\mathrm{Y}$} \\
\hline & Coeff. & SE & $p$ & Coeff & $\mathrm{SE}$ & $p$ & Coeff & SE & $p$ \\
\hline $\mathrm{X}_{1}(\mathrm{ATN})$ & .04 & .03 & .26 & .46 & .05 & $.00 *$ & -.04 & .06 & .51 \\
\hline $\mathrm{X}_{2}$ (ATV) & .40 & .06 & $.00 *$ & -.06 & .08 & .43 & .40 & .09 & $.00 *$ \\
\hline $\mathrm{X}_{3}(\mathrm{P})$ & .01 & .04 & $.01 *$ & .08 & .05 & .14 & -.18 & .06 & $.00 *$ \\
\hline $\mathrm{M}_{1}$ (Conv.) & - & - & - & - & - & - & .40 & .10 & $.00 *$ \\
\hline $\mathrm{M}_{2}$ (Conf.) & - & - & - & - & - & - & -.24 & .07 & $.00 *$ \\
\hline Constant & 1.27 & 2.10 & .55 & 6.11 & 3.10 & .05 & 26.09 & 3.26 & $.00 *$ \\
\hline $\mathrm{F}$ & & 23.83 & & & 30.50 & & & 13.02 & \\
\hline $\mathrm{R}^{2}$ & & .25 & & & .30 & & & .20 & \\
\hline
\end{tabular}

Table 3 shows that there is an indirect relationship between authoritative parenting style and empathy in children through conversation orientation, with an indirect effect score of $.16, \mathrm{SE}=.04$, and 95\% confidence interval: .08, .27 (BootLLCI, BootULCI). This data explains that conversation orientation of family communication patterns partially mediates the correlation between authoritative parenting style and empathy in children. Similarly, conversation orientation in family communication patterns also partially mediates the correlation between permissive and empathy in children. This is supported by the indirect effect score of $.04, \mathrm{SE}=.02$, and $95 \%$ confidence interval: $.01, .01$. Figure 1 shows the mediating role of conversation orientation on the relationship between parenting style and emphaty among children.

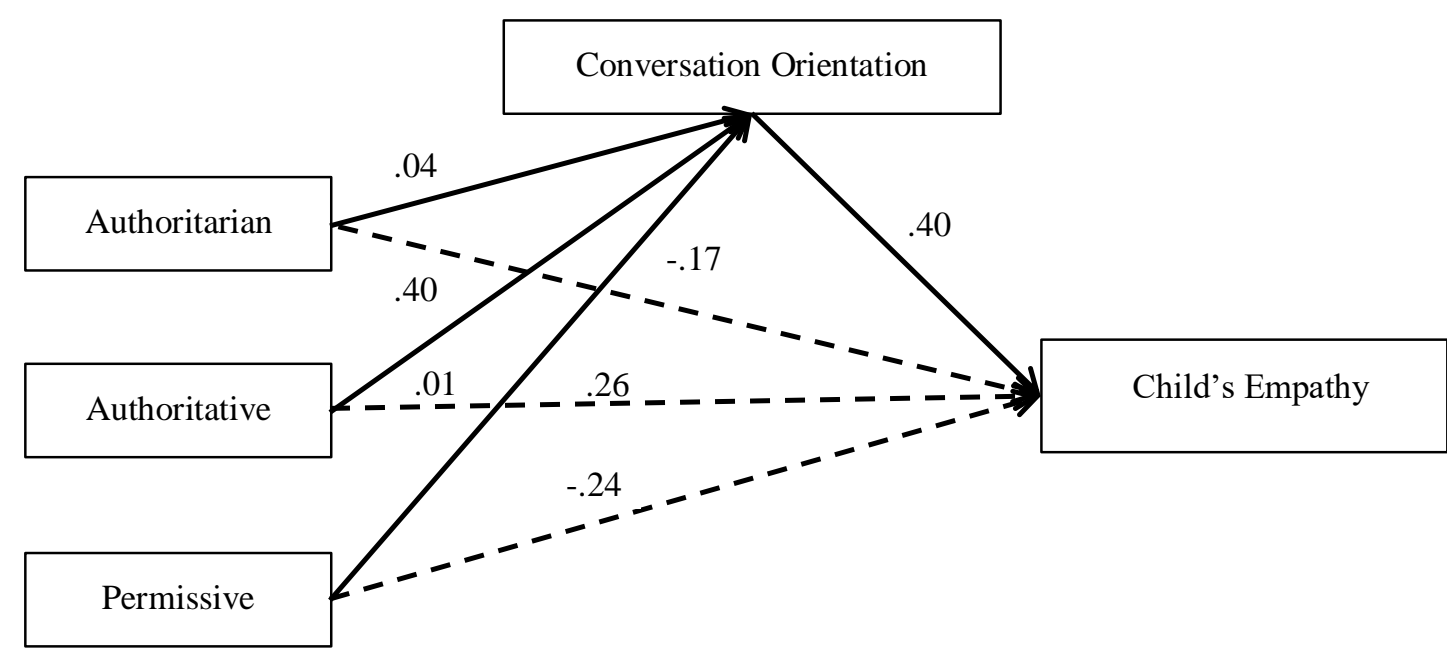

Figure 1. Direct and indirect effect between parenting style and empathy in children through conversation orientation dimension

Table 3 also shows that the indirect correlation between authoritarian parenting style and empathy in children through conformity orientation has an indirect effect score of -.11, $\mathrm{SE}=.03$, and $95 \%$ confidence intervals: $-.17,-.05$. This data indicates that conformity orientation in family communication patterns fully mediates the relationship between authoritarian parenting style and empathy in children. Figure 2 shows the mediating role of conformity orientation on the relationship of parenting style and emphaty among children. 


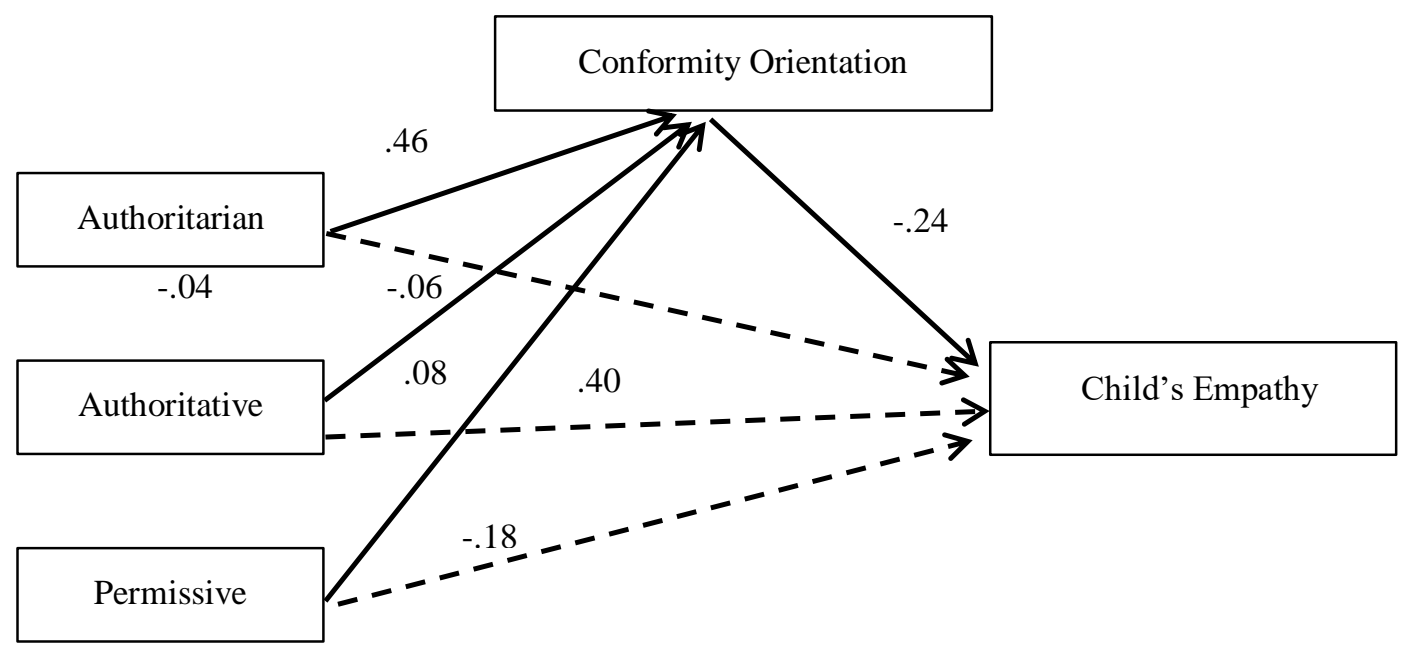

Figure 2. Direct and indirect effect between parenting style and empathy in children through conformity orientation dimension

\section{Discussion}

This study found that family communication patterns acts as a mediator of the relationship between parenting styles and empathy in children. Parenting style affects children's empathy through family communication patterns. This finding is in line with research conducted by Farokhzad (2015), which highlighted that family communication is related to parenting styles and could influence children. One of the influences is on the development of empathy in children. Based on several studies, Thompson (2014) concluded that parent-child communication contributes to the moral development of children.

Conformity orientation in family communication patterns is described by Koerner and Fitzpatrick (2002) as a pattern, shown by family members, that illustrates the extent to which each family member emphasizes similar attitudes, values, and beliefs. In other words, an authoritarian parenting style can reduce the development of empathy in children. On the other hand, when the family communication patterns are applied, the parenting style emphasizes more on the attitudes, values, and beliefs of each family member.

Parents who adopt an authoritative parenting style tend to use conversation orientation communication pattern, wherein the orientation in family communication will later affect the correlation between authoritative parenting style and empathy in children. The conversation orientation in family communication pattern is described as the extent to which family members support each other to act freely and comfortably in interacting, discussing, and communicating specific matters (Koerner \& Fitzpatrick, 2002). In other words, an authoritative parenting style can further improve empathy when family members apply communication patterns that tend to support each other to interact, discuss, and communicate freely and comfortably about certain topics or issues.

Furthermore, parents who adopt the permissive parenting style also tend to have conversation orientation communication pattern, where further orientation in family communication will affect the correlation between the permissive parenting style and the development of empathy in children. In other words, permissive parenting can further improve a child's empathy when family members apply conversation orientation 
communication patterns where each member supports each other to interact, discuss, and communicate freely and comfortably about topics, ideas, or particular issues.

The results of the translation of the data proved the role of conformity orientation in family communication patterns as a mediator between authoritarian parenting style and empathy in children. It illustrates that parents who adopt authoritarian parenting tend to have a family communication pattern with a conformity orientation. This orientation in family communication will affect the correlation between authoritarian parenting style and empathy in children.

The correlation between parenting style and empathy in children is proven in this study, where authoritative parenting has a positive correlation towards child empathy and permissive parenting has a negative correlation towards child empathy. This finding is in line with previous research conducted by Solfema (2013) that parenting style has a significant correlation with the development of empathy in children.

The current findings indicate that authoritative parenting has a positive effect on empathy in children, indicating that such parenting style could increase the latter. The results of this study are in line with the research conducted by Timpano, Keough, Mahaffey,

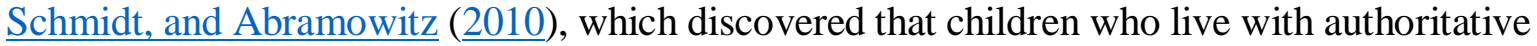
parents demonstrate higher levels of empathy. Authoritative parents are characterized by stability, affection, and monitoring that have an impact on children's emotions (Melnick \& Hinshaw, 2000). Children can understand and develop a higher level of empathy by learning through the experiences they have with their authoritative parents.

These results also indicate that of the three parenting styles, authoritarian and permissive parenting negatively affects empathy in children. In other words, authoritative and permissive parents could inhibit the development of empathy in children. Research conducted by Sidanius et al. (2013) showed that individuals with a dominant social orientation (authoritarian) would influence the level of empathy and compassion they have towards others. Additionally, Baumrind (1971) stated that parents with authoritarian pattern tend to use physical punishment, yelling, and command. As the primary agent of socialization in children's lives, authoritative parents rarely show empathy and compassion, being more likely to bring withdrawn and disruptive attitudes to children (Querido, Warner, \& Eyberg, 2002). Such conditions could pose more difficulties for children to produce empathetic behavior. Previous research shows that children with permissive parents exhibit poor self-control, low self-esteem, and aggression (Power, 2013), with the latter indicating low levels of empathy.

The correlation between parenting style and family communication patterns is also found in this study. However, the pattern of the correlation between parenting style and family communication patterns of this study is different from previous research in Iran (Farokhzad, 2015). In this study, authoritarian and permissive parenting have a positive correlation on conformity and conversation orientation. Meanwhile, in the study by Farokhzad (2015), authoritarian and permissive parenting only have a positive correlation with conformity orientation. This may be due to cultural differences, where some evidence suggests that ethnicity and race of the family can affect the different patterns and effects of parenting (Belsky, 2005). Culturally, Indonesian society is very diverse and has more than 200 different ethnicities, leading to each parent potentially having different cultural and parenting values (Kuntoro, Peterson, \& Slaughter, 2017). Riany et al. (2017) mentioned that, in general, Indonesia is strongly influenced by the modern environment and rapid cultural changes. This fact allows Indonesian parents to apply more Western cultural values and orientation compared to some East Asian societies.

The similarity of the results of this study and Farokhzad (2015) is that the authoritative parenting style has a positive correlation with conversation orientation. Baumrind (1971) stated that authoritative parents provide useful guidance for children, allowing them to build rational thoughts before acting, through open communication, positive interaction, and discussion. This situation reflects the character of a conversation orientation pattern. Other 
similar results to Farokhzad (2015) related to parenting style and family communication patterns is that the authoritarian and permissive parenting style has a positive correlation with conformity. This is in line with Koerner's (2014) statement that authoritarian parenting style is characterized by a lack of parental supervision of children's thoughts and feelings related to conformity orientation. This also applies to permissive parenting styles which are characterized by a lack of rules and parental supervision.

Parents could increase empathy in children in several ways. First, parents could apply parenting styles that give explanation, direction, and aid to children to form rational thinking before acting on any potentially aggressive impulse. Borba (2001) described that providing an explanation to children about the basic concept of emotion and the importance of understanding others' feelings could increase their level of empathy. Such explanations need to be done openly and positively in the form of interactions and discussions. Second, parents could provide examples to strengthen their explanation. Bandura (1991) suggested a modeling concept that involves role models for children. Parents are an essential role model in exemplifying empathic behavior in children, by giving warmth and affection to their children. Third, as explained by Bronfenbrenner through the ecological theory, the environment around children also plays a role in forming the child into an individual, including their empathy development (Santrock, 2011). When the environment is formed positively (i.e., open to differences of opinion, does not force the opinion of one party, respects each other, and supports children to implement empathic behavior), then the child would be more motivated to empathize with those around them.

There are several limitations and recommendations in this study that must be noted. First, data on empathy in children was only obtained through the parents' report. This type of report could be more valid and objective when combined using a multimethod approach, such as observation or multiple informants (Sánchez-Pérez et al., 2014). In this study, a large number of participants made it difficult to conduct multimethod approaches or multiple informants. Second, the participants in the present study only consisted of parents from six elementary schools in Jakarta. Future research may consider greater number of samples by expanding the research locations to include those outside of Jakarta as well as diverse settlement types or regions (e.g., Java, Kalimantan, Sumatera) to increase the generalization of the research findings and understanding the influence of culture. Finally, other environments that affect children's empathy need to be considered, such as the school environment. For instance, future studies may investigate the role of teachers or peers in a school environment. Therefore broadening information will be obtained, so that will gather strategies to increase empathy in children through the role of teachers, peers, and parents.

\section{Conclusion}

Family communication patterns has a role in mediating the correlation between parenting style and empathy in children. Furthermore, the role of family communication patterns as a mediator between parenting style and empathy in children occurs in both conversational and conformity communication. Conversational communication pattern mediate the effect of both authoritative and permissive parenting to child's empathy independently. Meanwhile, conformity communication pattern only mediate the influence of authoritarian parenting on children's empathy. Therefore parents have a critical role in developing empathy in their children in terms of parenting syle and family communication applied. 


\section{References}

Akhtar, Z. (2012). The effect of parenting style of parents on the attachment styles of undergraduate students. Language in India, 12(1), 555-566.

Bandura, A. (1991). Social cognitive theory of moral thought and action. In W. M. Kurtines, J. Gewirtz, \& J. L. Lamb (Eds.), Handbook of Moral Behavior and Development (1st ed., pp. 45-104). New York: Psychology Press.

Baron-Cohen, S., \& Wheelwright, S. (2004). The empathy quotient: an investigation of adults with asperger syndrome or high functioning autism, and normal sex differences. Journal of Autism and Developmental Disorders, 34(2), 163-175. https://doi.org/10.1023/B:JADD.0000022607.19833.00

Baumrind, D. (1971). Current patterns of parental authority. Developmental Psychology, 4(1 PART 2), 1-103. https://doi.org/10.1037/h0030372

Belsky, J. (2005). Family influences on psychological development. Psychiatry, 4(7), 4144. https://doi.org/10.1383/psyt.2005.4.7.41

Berns, R. M. (2013). Child, family, school, community: Socialization and support (9th ed.). Stamford, CT: Cengage Learning.

Borba, M. (2001). Building moral intelligence: the seven essential virtues that teach kids to do the right thing. San Francisco: Jossey Bass.

Children as Criminals Increase. (n.d.). Retrieved January 1, 2018, from http://rakyatkaltara.prokal.co/read/news/10976-anak-sebagai-pelaku-kejahatanmeningkat.html

Cornell, A. H., \& Frick, P. J. (2007). The moderating effects of parenting styles in the association between behavioral inhibition and parent-reported guilt and empathy in preschool children. Journal of Clinical Child and Adolescent Psychology, 36(3), 305318. https://doi.org/10.1080/15374410701444181

Darling, N., \& Steinberg, L. (1993). Parenting style as context: An integrative model. Psychological Bulletin, 113(3), 487-496. https://doi.org/10.1037/0033-2909.113.3.487

Farokhzad, P. (2015). Childrearing styles and family communication patterns among university students. International Journal of Psychological and Behavioral Sciences, 9(5), 1711-1716.

Gantiva, C., \& Cendales, R. (2018). Is there really a relationship between empathy and aggression? Evidence from physiological and self-report measures. Journal of Interpersonal Violence, 1-21. https://doi.org/10.1177/0886260518776999

Gilli, S. (2016). Gender bias in parenting styles and its contribution to gender differences in empathy. University of Cape Town, South Africa.

Halim, D. (2019). Kasus anak berhadapan dengan hukum tetap tertinggi (Child cases dealing with law, the highest dominated sexual crimes). Retrieved from Kompas website: https://beritagar.id/artikel/berita/kasus-anak-berhadapan-dengan-hukum-tetaptertinggi

Hinton, P. R., Brownlow, C., McMurray, I., \& Cozens, B. (2004). SPSS explained. London: Routledge.

Hoffman, M. L. (2000). Empathy and moral development: Implication for caring and justice. Cambridge: Cambridge University Press. https://doi.org/10.1017/CBO9780511805851.

Kiare, J. W. (2015). Influence of parental characteristics on preschool children's moral development in Nairobi Country, Kenya. University of Nairobi, Kenya. 
Koerner, A. F. (2014). Family communication. In C. R. Berger (Ed.), Interpersonal communication: Handbook of communication science (pp. 419-441). Davis: De Gruyter Mouton.

Koerner, A. F., \& Fitzpatrick, M. A. (2002). Understanding family communication patterns and family functioning: The roles of conversation orientation and conformity orientation. Annals of the International Communication Association, 26(1), 36-65. https://doi.org/10.1080/23808985.2002.11679010

Kong, A., Thorleifsson, G., Frigge, M. L., Vilhjalmsson, B. J., Young, A. I., Thorgeirsson, T. E., \& ... Stefansson, K. (2018). The nature of nurture: Effects of parental genotypes. Science, 359(6374), 424-428. https://doi.org/10.1126/science.aan6877

Kuntoro, I. A., Peterson, C. C., \& Slaughter, V. (2017). Culture, parenting, and children's theory of mind development in Indonesia. Journal of Cross-Cultural Psychology, 48(9), 1389-1409. https://doi.org/10.1177/0022022117725404

McDonald, N. M., \& Messinger, D. S. (2011). The development of empathy: How, when, and why. In J. J. Sangineti, A. Acerbi, \& J. A. Lombo (Eds.), Moral behavior and free will: A neurobiological and philosophical aprroach (pp. 341-368). London: If Press.

Melnick, S. M., \& Hinshaw, S. P. (2000). Emotion regulation and parenting in AD/HD and comparison boys: Linkages with social behaviors and peer preference. Journal of Abnormal Child Psychology, 28(1), 73-86. https://doi.org/10.1023/A:1005174102794

Morelli, S. A., Lieberman, M. D., \& Zaki, J. (2015). The emerging study of positive empathy. Social and Personality Psychology Compass 9/2 (2015), 57-68. https://doi.org/10.1111/Spc3.12157

Power, T. G. (2013). Parenting dimensions and styles : A brief history and recommendations for future research. Childhood Obesity, 9(August), 14-21. https://doi.org/10.1089/chi.2013.0034

Primastika, W. (2018). Penyebab kriminalitas anak: Kurang kasih sayang pengakuan sosial (Cause of Criminality on children: Lack of affection and social recognition).

Querido, J. G., Warner, T. D., \& Eyberg, S. M. (2002). Parenting styles and child behavior in African American families of preschool children. Journal of Clinical Child \& Adolescent Psychology, 4416(October 2014), 37-41. https://doi.org/10.1207/S15374424JCCP3102

Reitman, D., Rhode, P. C., Hupp, S. D., \& Altobello, C. (2002). Development and validation of the Parental Authority Questionnaire-Revised. Journal of Psychopathology and Behavioral Assessment, 24(2), 119-127. https://doi.org/10.1023/A:1015344909518

Riany, Y. E., Cuskelly, M., \& Meredith, P. (2017). Parenting style and parent-child relationship: A comparative study of Indonesian parents of children with and without autism spectrum disorder (ASD). Journal of Child and Family Studies, 26(12), 35593571. https://doi.org/10.1007/s10826-017-0840-3

Sánchez-Pérez, N., Fuentes, L. J., Jolliffe, D., \& González-Salinas, C. (2014). Assessing children's empathy through a Spanish adaptation of the Basic Empathy Scale: Parent's and child's report forms. Frontiers in Psychology, 5(DEC), 1-13. https://doi.org/10.1007/s10826-017-0840-3

Sangawi, H. S., Adams, J., \& Reissland, N. (2015). The effects of parenting styles on behavioral problems in primary school children: A Cross-cultural review. Asian Social Science, 11(22), 171-186. https://doi.org/10.5539/ass.v11n22p171

Santrock, J. W. (2011). Child development: An introduction. New York: McGraw-Hill.

Shaffer, D. R., \& Kipp, K. (2014). Developmental psychology: Childhood \& adolescence. USA: Wadsworth.

Sidanius, J., Kteily, N., Sheehy-skeffington, J., Ho, A. K., Sibley, C., \& Duriez, B. (2013). 
You're inferior and not worth our concern: The interface between empathy and social dominance orientation. Journal of Personality, 81(3), 313-323. https://doi.org/10.1111/jopy.12008

Solfema. (2013). Parenting styles, school culture, society culture, and teenagers' empathy. Journal of Science Education, 19(2), 149-154. https://doi.org/10.17977/jip.v19i2.4206

Telle, N. T., \& Pfister, H. R. (2015). Positive empathy and prosocial behavior: A neglected link. Emotion Review, 8(2), 154-163. https://doi.org/10.1177/1754073915586817

Thompson, R. A. (2014). Conscience development in early childhood. In M. Killen \& J. G. Smetana (Eds.), Handbook of Moral Development (2nd ed., pp. 73-92). New York: Psychology Press.

Timpano, K. R., Keough, M. E., Mahaffey, B., Schmidt, N. B., \& Abramowitz, J. (2010). Parenting and obsessive compulsive symptoms: Implications of authoritarian parenting. Journal of Cognitive Psychotherapy, 24(3), 151-164. https://doi.org/10.1891/08898391.24.3.151

Vieira, E. T. (2015). Family communication patterns, sympathy, perspective-taking, and girls' thoughts about interpersonal violence. Journal of Family Violence, 30(5), 607619. https://doi.org/10.1007/s10896-015-9705-y 